KAMILA KUROS-KOWALSKA

(D) https://orcid.org/0000-0002-3618-4927

Uniwersytet Śląski w Katowicach

Katowice

\title{
Percepcja zmian w języku polskim u uczniów dwujęzycznych w Anglii (na przykładzie słownictwa młodzieżowego)
}

\author{
Perception of changes in the Polish language in bilingual students in England \\ (using the example of youth vocabulary)
}

\begin{abstract}
The paper presents the results of research making it possible to reflect for instance on whether staying in a multicultural environment makes one break bonds with the living Polish language. The tool used to seek an answer to this question was a survey checking the understanding of the most popular youth words of the recent years. The youth word of the year, chosen every year, makes it possible to discover the features of the Polish language used by the young generation. The competition makes it possible to explore and follow the linguistic fashion. Words classified as youth words are not necessarily new or slang ones, but they are used much more often by the analysed group. The survey covered more than 200 students attending Polish community schools in the UK. The results were compared to those related to a group of young people from Poland.
\end{abstract}

Keywords: youth vocabulary, Polish language, bilingual student

Mówiąc, wyrażamy myśli, zdania, uczucia, czyli komunikujemy się. Ludzie na całym świecie porozumiewają się za pomocą słów, ale nawet jeśli wydaje się, że konkretna grupa prowadzi rozmowę w swoim własnym, ojczystym języku, to nie jest on taki sam jak mowa innej społeczności (łączącej ludzi o odmiennych cechach wspólnych). Różnice zależą od miejsca używania języka, ale także od tego, przez kogo jest używany i w jakiej sytuacji. Nastolatki posługują się charakterystyczną odmianą polszczyzny, jaką jest środowiskowy język młodzieżowy, który różni się od sposobu mówienia osób dorosłych. Oczywistym kryterium wyodrębniającym użytkowników socjolektu 
młodzieżowego jest ich wiek. Na potrzeby niniejszej publikacji stosuję termin ,język młodzieżowy” i mam na myśli język grupy społecznej uczniów w określonym wieku (11-18 lat).

W mowie młodzieży także wyróżnia się dwie odmiany: oficjalną i nieoficjalna, w zależności od tego, czy młode osoby rozmawiają ze soba, czy np. z dorosłymi (Ożóg 2002, 521). To, w jaki sposób młodzież między soba rozmawia, jest tożsame z nieoficjalną odmianą polszczyzny (Ożóg 2004, 179). Badacze od dawna zwracają uwagę na komizm, ironię i radykalny osąd rzeczywistości, który charakteryzuje język młodzieżowy (Zgółkowa 1991; Kowalikowa 1996; Ożóg 2002; Pilczuk B. i A. 2013). Odmienność języka młodzieżowego ma określone cele. Z jednej strony służy budowaniu pozycji w grupie rówieśniczej (tworzenie oryginalnych i dowcipnych wypowiedzi, a przy tym wysoka sprawność językowa wpływa na pozytywny obraz siebie). Język ma też duże znaczenie w kształtowaniu się samooceny (Kulas 1986; Gajda 1987). Z drugiej strony buduje relacje w grupie. Mówienie tym samym językiem jest opisywane jako rodzaj dopuszczania kogoś do tajemnicy. Ograniczanie pozostałym osobom możliwości rozumienia komunikatów służy odseparowaniu, a także odłączeniu się od innych, zwłaszcza dorosłych (Pilczuk B. i A. 2013, 16). Bożena Pilczuk i Aleksandra Pilczuk, opisując zalety języka młodzieżowego, przytaczały wypowiedzi uczniów, którzy sami zwracali uwage na to, że ich język daje możliwość szybszego porozumiewania się ze soba. Okazuje się, że młodzi ludzie są świadomi samodzielnego „przeprowadzania ekonomizacji języka” (Pilczuk B. i A. 2013, 17). Język jest swoistym zwierciadłem, w którym dostrzec można nie tylko słowa, ale także punkt widzenia prezentowany przez daną grupę. W trakcie próby opisu warto zatem wspomnieć o dynamiczności zmian. Każde pokolenie tworzy swój własny kod, który można rozpatrywać w kategoriach wtajemniczenia.

Język młodzieży oscyluje między kodem rozwiniętym a ograniczonym. Opozycję kodu rozwiniętego i ograniczonego jako pierwszy wprowadził B. Bernstein, który opierał się właśnie na obserwacji mowy młodzieży w Anglii (Ożóg 2002, 521). Kazimierz Ożóg zauważa w języku młodzieży modę na bylejakość mówienia, dużą swobodę, akcentowanie swojej niezależności, poszukiwanie przyjemności, emocjonalizacje doświadczeń, trywializowanie, opieszałość, wreszcie: ogromne oddziaływanie środków masowego przekazu (Ożóg 2002, 522). Badacz zwrócił uwagę na istotne kręgi semantyczne, pojawiające się w omawianej odmianie, komponenty kodu ograniczonego, wymienił wśród nich: nastawienie na kontakt i komunikat; cechy fizyczne, psychiczne i zachowanie człowieka; relacje między uczestni- 
kami grupy młodych ludzi; części ciała; różne przedmioty; intensywność stanu (radykalizm wyrażania ocen); procesy intelektualne, stany psychiczne człowieka; rozrywkę; szkołę; seks; modne powiedzonka; wulgaryzmy (Ożóg 2002, 523-524). Językoznawcy (Pisarek 1991; Bartmiński 2001, 120-124; Pachowicz 2018, 31) zauważają, że język młodzieży charakteryzuje odrębna leksyka i frazeologia, korzysta on z polszczyzny ogólnej i języka potocznego (głównie z zakresu emocjonalnego i swobodnego), zdaniem Grabiasa „ze wszystkich odmian polszczyzny" (Grabias 2001, 252).

Mowa młodych jest interesujacym socjolektem zwłaszcza z uwagi na swe bogactwo, różnorodność i dynamiczną zmienność. Świadczy o tym m.in. humor widoczny w wymowie takich słów, jak: dzięes, dżampreza, spoxon oraz osobliwy zapis, np.: pozdroofki; a także tworzenie derywatów od zapożyczeń angielskich (sorki, sorka, sorewicz, podensić, pliski, afterek, biforek). Popularność anglicyzmów jest cechą popkultury, natomiast derywaty są efektem adaptowania obcych słów na język polski. Im trudniejszy, bardziej skomplikowany słowotwórczo wyraz, tym silniej wchodzi do systemu, np. boyfriendy, fashionistka, broker. Młodzież jest skłonna do zabawy językiem, stąd tak wiele gier językowych zarówno w tekstach tak pisanych, jak i mówionych. W literaturze nie brakuje opinii, że do cech mowy młodych członków społeczności można zaliczyć akronimy. Są one jednak cechą dyskursu komunikacji internetowej, czyli Netspeaku (Dzioba 2005, 466). Wyrazy tworzone przez młodzież są nacechowane emocjonalnie, stąd w ich języku tak wiele ekspresywizmów. Grupa ta często nadużywa tych samych słów (np. fajnie, wow, super), choć zakres znanej biernie synonimii raczej nie jest ubogi.

Wielość terminów i nazw, które stosuje się do opisywania języka młodzieży, pozwala zauważyć, że ten socjolekt jest „niezwykle wybuchową mieszanką językową fascynującą naukowców, dziennikarzy i zwykłych ludzi” (Czeszewski 2001, VII), a także „świadectwem językowej inwencji, spontaniczności” (Chaciński 2003, 8).

W trakcie rozważań nad zastosowaniem języka młodzieży można dojść do wniosku, że przede wszystkim (dzięki posługiwaniu się np. skrótowcami) zmierzają oni w stronę ekonomii porozumiewania się. Młode pokolenie dąży do upraszczania, skracania także form i formuł (Marcjanik 2008, 72). Młodzież przewartościowuje podstawowe funkcje języka, dominująca staje się dla nich funkcja ludyczna, fatyczna oraz perswazyjna. W ich komunikacji wyraźna jest emocjonalizacja wypowiedzi oraz liczne zapożyczenia, czemu służy wykorzystywanie leksyki potocznej. Nastolatkowie kreuja modę językową na konkretne słowa. Wyrażają tym samym charakterystyczny dla nich 
sposób przeżywania i widzenia rzeczywistości. Tworzenie własnego języka daje młodym ludziom poczucie indywidualizmu.

\section{Opis materiału badawczego}

Analizowany przeze mnie materiał badawczy to leksyka młodych - tzw. młodzieżowe słowa wyekscerpowane ze strony internetowej Wydawnictwa Naukowego PWN, które od kilku lat organizuje plebiscyt na Młodzieżowe Słowo Roku. Celem głosowania jest wyłonienie najpopularniejszych wśród młodych ludzi słów bądź wyrażeń. W 2016 r. wygrało słowo sz̧tos, czyli 'coś fajnego, niesamowitego', które może określać wszystko. W 2017 r. młodzieżowym słowem roku zostało funkcjonujące głównie w języku mediów społecznościowych XD, czyli znak ikoniczny, który może być również zapisywany jako iksde. W roku 2018 plebiscyt zwyciężyło określenie dæ̧ban oznaczające 'osobę nierozgarnięta, niezbyt inteligentną. Leksemy, o które została zapytana młodzież w przygotowanej przeze mnie ankiecie, to: sžtos, džban, masny, prestiżony, pocisk, ogar, beczka, które w ostatnich latach cieszyły się największym powodzeniem. Może zastanawiać, dlaczego akurat te wskazane wyrazy stały się tak popularne wśród młodych osób. Językoznawcy komentujący wybór zwracali uwagę, jak duże znaczenie odgrywa oryginalność fonetyczna nowych słów (komentarz Marka Lazińskiego1). Bartek Chaciński zauważa: „wyniki plebiscytu pokazują że nie tyle coraz szybciej zmienia się polszczyzna, co raczej coraz mocniejszy wpływ mogą mieć na nią - w czasach mediów społecznościowych - działania pojedynczych, konkretnych osób”2. Osoby, o których wspomina Chaciński, to youtuberzy (np. Klocuch czy Lord Kruszwil), którzy dla młodzieży stają się wzorem do naśladowania - także językowego. W konkursie najczęściej powtarzały się wyrazy związane z oceną i emocjami (np. dz̧ban, beczka), dotyczące rozmów, sporów i prowokacji (np. pocisk, ogar). Z kolei popularność np. prestižn, który w języku młodzieżowym jest leksemem niezwykle uniwersalnym, związana jest z wcześniej wspomnianym youtuberem Lordem Kruszwilem (to on zapoczatkował modę na używanie tego wyrazu). Zapożyczone z gwary śląskiej słowo masny najczęściej było definiowane synonimicznie w stosunku do leksemu grubo.

\footnotetext{
${ }^{1}$ https://sjp.pwn.pl/ciekawostki/haslo/Rozstrzygniecie-plebiscytu-mlodziezowe-slowo-ro ku-2018-komentarz-Marka-Lazinskiego;6477396.html [dostęp: 20.05.2019 r.]

2 https://sjp.pwn.pl/ciekawostki/haslo/Rozstrzygniecie-plebiscytu-mlodziezowe-slowo-ro ku-2018-komentarz-Bartka-Chacinskiego;6477398.html [dostęp: 20.05.2019 r.]
} 


\section{Opis grupy badawczej}

Grupa badawczą w przeprowadzonych przeze mnie badaniach byli nastolatkowie ze szkół polonijnych z Anglii Północnej, którzy w większości urodzili się w Polsce i spędzili w niej pierwsze lata życia. We wczesnych latach swojego dzieciństwa przyswoili język polski. Po wyjeździe do nowego kraju pobierają oni naukę wyłącznie $\mathrm{w}$ języku angielskim w szkołach angielskich, a w szkołach polonijnych spędzaja jedynie kilka godzin w tygodniu. Wybrana przeze mnie grupa badawcza pomiędzy 11. a 18. rokiem życia uczęszcza do szkół sobotnich w następujących miastach: Hull, Preston, Carlisle, Lancaster, Liverpool, Blackburn, Coventry, Manchester. Łącznie zebrałam ankiety od 235 uczniów w Anglii. Grupa porównawczą była młodzież ze szkół w Polsce (Sosnowiec), otrzymałam formularze od 190 uczniów w naszym $\mathrm{kraju}^{3}$. Z uwagi na wspomniane powyżej zapożyczenie jednego ze słów z gwary śląskiej, świadomie nie zdecydowałam się na przeprowadzenie ankiety wśród młodych ludzi uczących się czy pochodzących ze Śląska.

W kategoriach socjolingwistycznych młodzież określa się jako środowiskowa grupe przynależąca do danego pokolenia, które łączą wspólne więzi. Wybrane przeze mnie osoby sa członkami konkretnej grupy społecznej funkcjonującej w ramach określonych instytucji społecznych. Młodych ludzi łączy zatem język, którym się posługuja. Charakteryzuje się ich przez pryzmat trzech kryteriów: wieku, poglądów - systemu wartości oraz wykonywanej czynności, którą jest uczenie się (Pachowicz 2018, 29). Nastolatkowie należą do „kategorii osób społecznie niesamodzielnych" (Messyasz 2013, 40) z uwagi na fakt, że sa w trakcie procesu edukacji, nie są niezależni ekonomicznie ani zawodowo. W ramach procesu edukacji oraz socjalizacji gromadza oni „społeczne doświadczenie w formie określonych przepisów, wzorców, modeli, działania, postaw i zachowania" (Karwat, Milanowski 1981, 43).

\section{Narzędzie badawcze}

W badaniu posłużyłam się kwestionariuszem własnego autorstwa. Celem ankiety było przede wszystkim zebranie informacji na temat tego, czy mło-

\footnotetext{
3 Z uwagi na strajk nauczycieli w Polsce, który trwał w okresie prowadzenia przeze mnie badań, nie udało się zebrać ankiet od dokładnie takiej samej jak w Anglii liczby nastolatków w Polsce.
} 
dzież dwujęzyczna, ale i polska, zna młodzieżowe słowa. Ponadto istotne było dla mnie poznanie ulubionych młodzieżowych słów i uzyskanie odpowiedzi na pytanie, czy młodzi używają ich w kontaktach z rówieśnikami. W metryczce młodzież z Anglii udzielała dodatkowych informacji (bardzo istotnych dla wyciągnięcia wniosków) między innymi związanych ze sposobami komunikowania się w języku polskim. Każdy z uczniów w Anglii oraz w Polsce został poproszony o wyjaśnienie słów wskazanych w ankiecie:

1. Wyjaśnij, co znaczą następujące słowa. Jeśli znasz kilka znaczeń wyrazu, napisz wszystkie Ci znane.

- sztos

- dzban

- masny

- prestiżowy

- pocisk

- ogar

- beczka

2. Czy używasz wyżej wskazanych słów w komunikacji z rówieśnikami? TAK / NIE

3. Jakie jest Twoje ulubione młodzieżowe słowo w języku polskim, którego używasz, kontaktując się z rówieśnikami?

\section{Wyniki}

Poniżej przedstawione zostaną wyniki ankiety badającej znajomość młodzieżowych słów wśród grupy społecznej, którą wyróżnia podobny wiek oraz charakterystyczny język. Badania były prowadzone wśród młodzieży od lutego do maja 2019 r. Jeśli porówna się w całości grupę nastolatków z Polski z grupa z Anglii, to widać ogromną dysproporcje - na korzyść młodych osób mieszkających w ojczyźnie. Młodzi ludzie przebywający w Polsce reprezentują wysoki poziom znajomości badanych słów charakterystycznych dla swojej grupy wiekowej.

Gdy jednak spośród grupy młodzieży z Anglii wybrane zostaną osoby znające co najmniej 4 słowa $z$ ankiety (co odpowiada w przybliżeniu młodzieży o relatywnie wysokiej ogólnej kompetencji językowej w języku polskim), można dokonać ciekawych spostrzeżeń dotyczacych tego, jak - w porównaniu z polskimi rówieśnikami - kształtowała się znajomość poszcze- 
gólnych leksemów. Słowa, z którymi przebywająca w Anglii młodzież o najwyższej kompetencji językowej miała największe trudności, to masny i pocisk. Znaczeń tych wyrazów albo w ogóle nie znali, albo podawali ich znaczenie słownikowe. Wysoka znajomość wyrazów młodzieżowych (poza wskazanymi powyżej) u młodych osób w Anglii, które znały ponad 4 słowa, świadczy o trafnym doborze materiału leksykalnego w badaniu. Okazuje się, że 5 z 7 pojęć należy do polskiego słownika młodzieżowego niezależnie od miejsca zamieszkania uczniów.
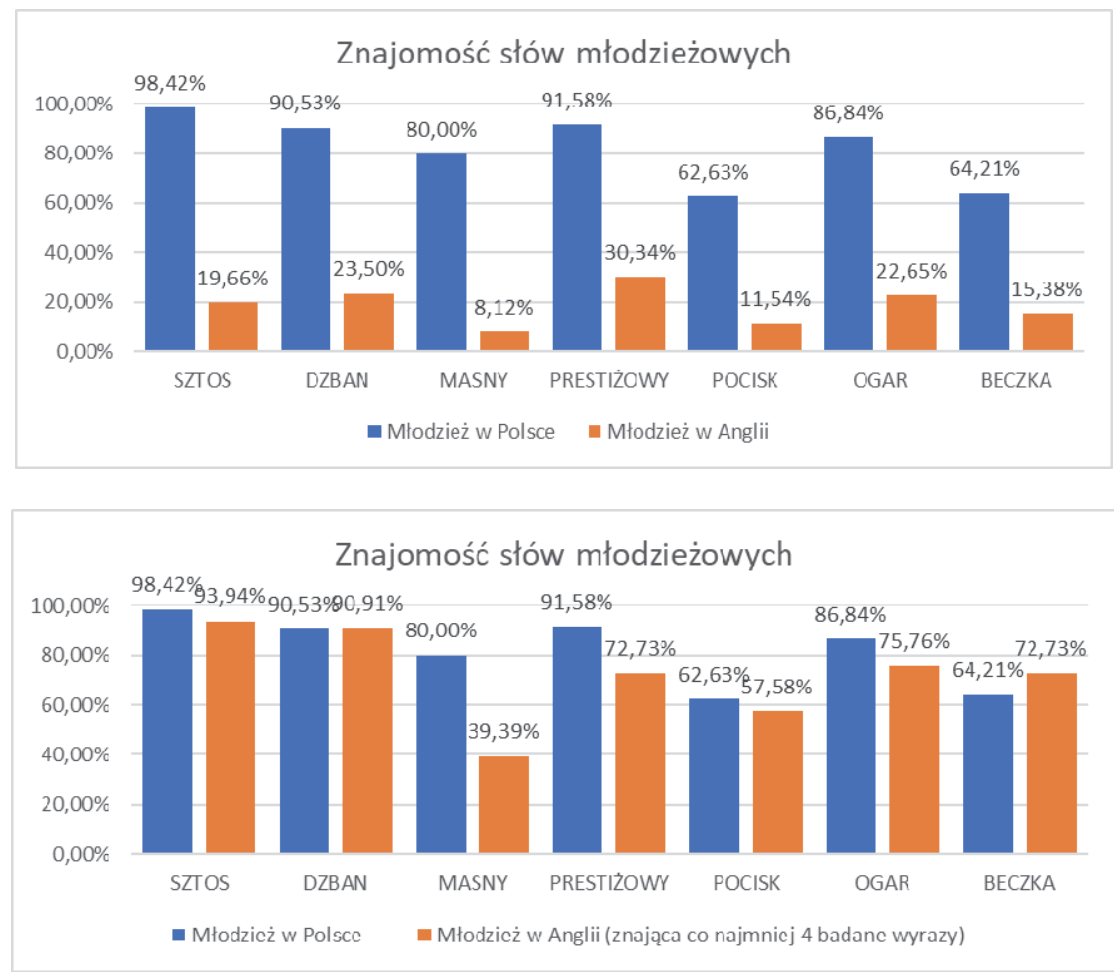

W drugim pytaniu młodzież została poproszona o odpowiedź, czy używa wskazanych w ankiecie wyrazów w komunikacji z rówieśnikami. W diagramach można zauważyć wyniki niemalże odwrotne w stosunku do obu grup. Polska grupa w znacznej większości (64,53\%) przyznaje, że korzysta z młodzieżowych słów roku w swoich kontaktach z rówieśnikami. Wśród młodzieży uczącej się w Anglii tylko 32,34\% używa wskazanych w ankiecie ter- 
minów w rozmowach z równolatkami. Warto zauważyć, iż nieużywanie młodzieżowych słów przez $100 \%$ przedstawicieli grupy w Polsce nie oznacza wcale, że nie rozumieją oni znaczenia tych terminów (co pokazały grafy przedstawione przy okazji omawiania wyników badań). Z kolei przykład młodzieży w Wielkiej Brytanii dowodzi, że jeśli nie używa się polskich słów w kontaktach z kolegami w określonym kontekście, to często nie zna się ich młodzieżowego znaczenia (tu wyniki także znajduja pokrycie w odpowiedziach ujętych już wcześniej).
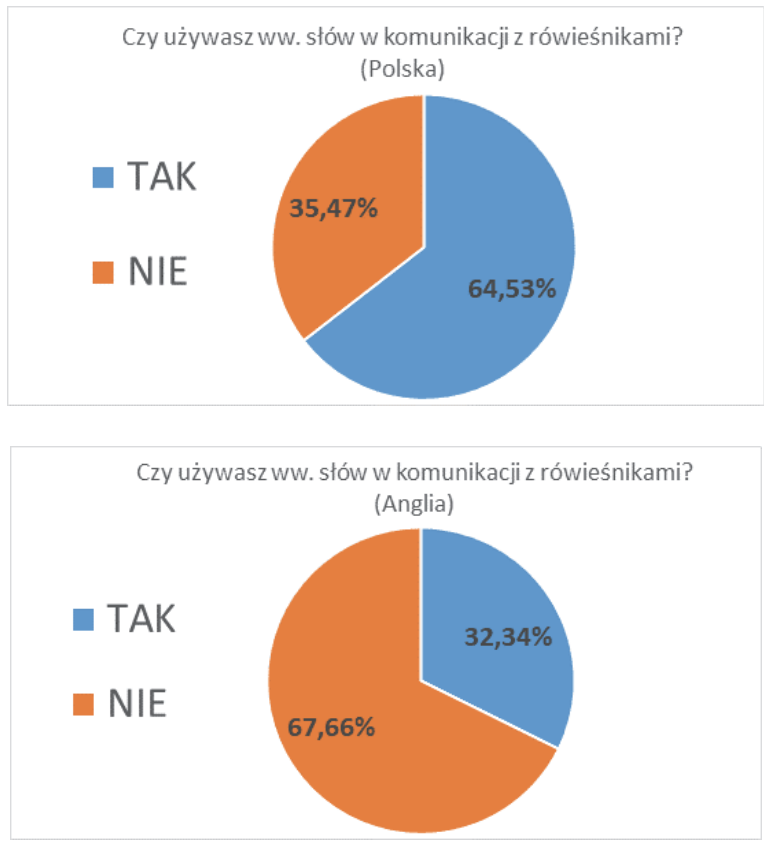

W trzecim pytaniu młodzież udzielała odpowiedzi na pytanie o ulubione młodzieżowe słowa w języku polskim, których używa w rozmowach z rówieśnikami ${ }^{4}$. Młodzież w Anglii wskazała następujące słowa: siema, gitara, ziomal, ziomek, super, fajnie, dzban, git, spoko, friko, toś, XD, heja, beka, bit, sqtos, bez. kitu, hejo, mega, pocisk. Natomiast młodzież w Polsce podawała takie wyrazy, jak: sqtos, dzban, prestižowy, kozacki, XD, masny, masno fest, siema, prestiz, ogar, beka, LOL, hej. Grupa ta wskazywała dodatkowo następujące skróty: kk - modyfikacja angielskiego „ok”, które oznacza zgodzenie się z czymś; zw -

4 Podkreślono słowa powtarzające się w obu grupach. 
zaraz wracam; thx - skrót od angielskiego „thanks”, czyli „dzięki”; btw z angielskiego: „by the way”, czyli „nawiasem mówiąc”.

Ostatnim elementem ankiety była tzw. metryczka dotycząca młodzieży z Anglii. Miała ona dostarczyć dodatkowych informacji, które mogły pomóc w prawidłowej interpretacji wyników. Młodzież, która znała ponad połowę ze wskazanych wyrazów, w znacznej większości urodziła się w Polsce (93,94\%). Spośród całej grupy (młodzieży w Anglii oraz w Polsce) blisko 64\% urodziło się w Polsce.

Metryczka dotycząca młodzieży z Anglii

\author{
Znajomość badanych słów \\ Urodzenie w Polsce
}

znający ponad połowę słów młodzieżowych

$0,00 \% 10,00 \% 0,00 \% 0,00 \% 0,00 \% 0,00 \% 0,00 \% 0,00 \% 0,00 \% 0,00 \% 00,00 \%$

- urodzeni w Polsce urodzeni za granicą

Młodzież oceniała znajomość języka polskiego według własnej opinii w mowie oraz w piśmie. Grupa o dobrej znajomości słów młodzieżowych oceniła się o połowę lepiej w mowie niż w piśmie (ocena bdb). W piśmie najwięcej osób przyznało sobie ocenę dobra (60,61\%). Więcej młodych ludzi jako przeciętne oceniło swoje pismo (15,15\%) niż swoją mowę (5,88\%).

Ostatnie pytanie w metryczce dotyczyło częstotliwości używania języka polskiego w różnych kanałach w grupie o dużej znajomości słów młodzieżowych. Młodzież w Anglii regularnie używa języka polskiego dzięki komunikowaniu się z innymi przez aplikacje i komunikatory, np. WhatsApp, Messenger, Wattpad, Snapchat, Skype, Telegram (aż 84,38\%). W drugiej kolejności nastolatkowie rozmawiaja ze sobą bezpośrednio (63,33\%), najczęściej w sobotnich polskich szkołach. Prowadzą konwersację w języku polskim także przez telefon (39,39\%). Bardzo rzadko posługują się polskim (33,33\%), a najczęściej nie robią tego w ogóle $(48,48 \%$ ) w korespondencji mejlowej. Zestawienie uzyskanych wyników z odpowiedziami na wcześniejsze pytanie pokazuje, iż młodzież ocenia swoja znajomość języka polskiego jako słabszą w piśmie niż mowie. Tym- 
czasem nastolatkowie najczęściej za pomocą komunikatorów kontaktują się z rówieśnikami w języku polskim. Z drugiej strony język, którym młodzi ludzie posługują się w różnych aplikacjach w telefonach lub komunikatorach świadczy o tym, że jest to jednak system mówiony, choć zapisany. Być może dlatego to właśnie swą mowę młodzież ocenia znaczenie lepiej.
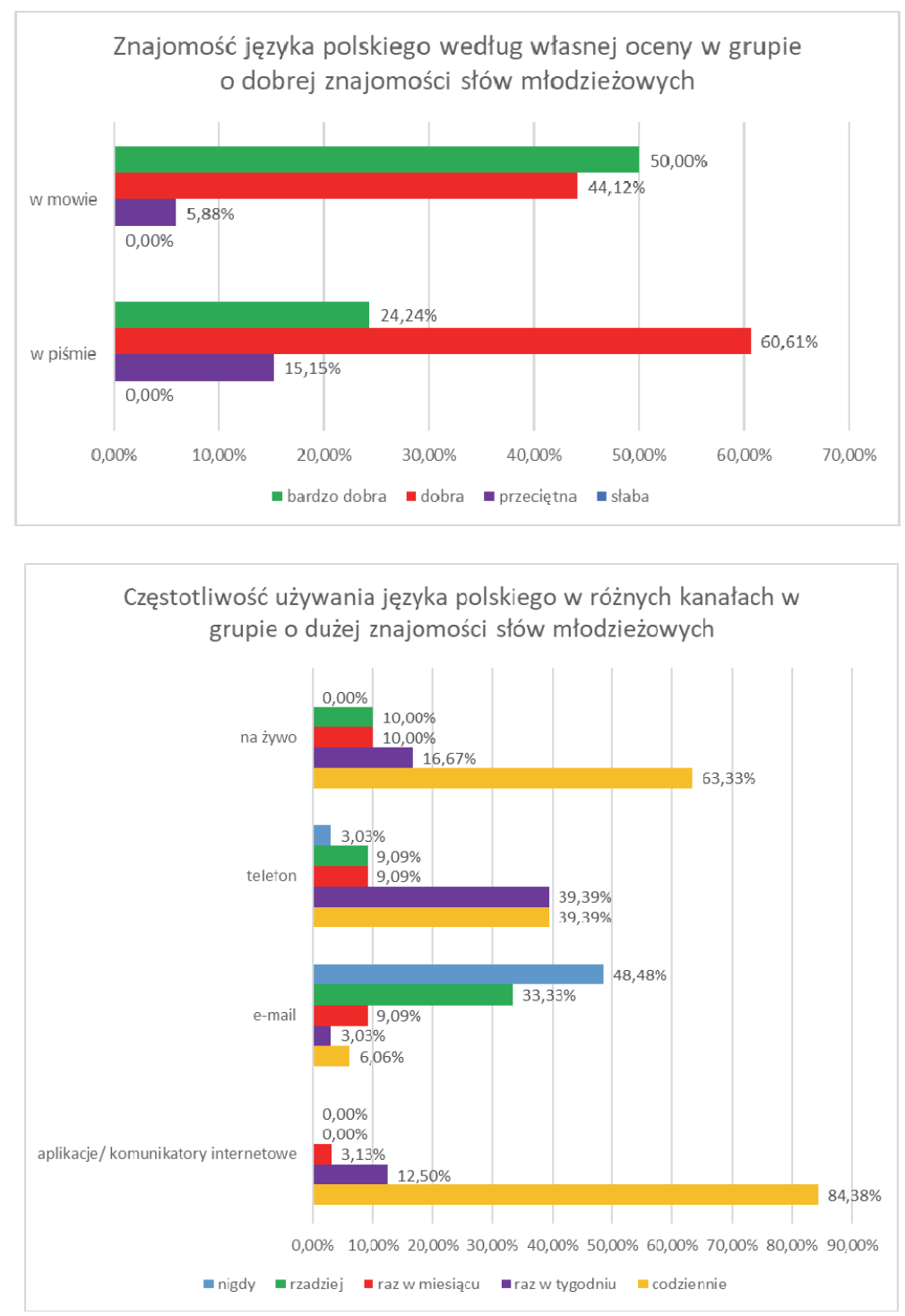


\section{Podsumowanie}

Dwujęzyczna młodzież nie ma tak częstego kontaktu z językiem polskim jak ich rówieśnicy z Polski. Jednak dzięki nowym technologiom i uczęszczaniu do polskich szkół młodzi ludzie za granicą mają świadomość zmian zachodzących w języku polskim, a także zmienności procesów tworzenia nowych słów, co wykazały wyniki badań. Ta wiedza może okazać się niezbędna w przypadku chęci studiowania w Polsce lub powrotu do kraju, w którym młodsi przedstawiciele społeczeństwa będą musieli się odnaleźć i rozumieć wypowiedzi swoich rówieśników. Postęp technologii daje zatem nowe możliwości nie tylko do badań oraz obserwacji czy analizy zjawisk językowych. Wpływa on także na zachowanie kontaktu z „,̇ywym językiem”, z czego korzysta młodzież przebywająca za granicą. Młodzi ludzie, którzy nie wykazują dostatecznej znajomości słownictwa, gorzej radzą sobie w procesie aktu komunikacji (Seretny 2010, 547).

Współczesne media dają możliwość komunikacji oraz podejmowania interakcji za pośrednictwem telefonu lub komputera, z czego najchętniej korzystają młodzi ludzie (Bałandynowicz 2018, 173). Warto zauważyć, że młodzież od urodzenia ma kontakt $\mathrm{z}$ internetem i telefonem komórkowym. Sa częścią społeczeństwa medialnego, sieciowego podlegającego ciagłej zmianie w wyniku przeobrażeń technologicznych (Tomaszewska 2012, 21). Media interaktywne wymuszaja pewne zachowania językowe ${ }^{5}$ (np. rozumienie młodzieżowych słów), a także kreują językowy obraz świata. Globalizacja, mediatyzacja kultury, tempo życia sprawiaja, że komunikacja ma często charakter instrumentalny. Tworzenie skutecznych a zarazem efektownych komunikatów ma największe znaczenie, co zdecydowanie zachęca nastolatków do używania młodzieżowych słów, które integrują tę wspólnotę pokoleniową i tworzą intersocjolekt.

Młodzi ludzie określają wzory zachowań dyskursywnych w swojej grupie wiekowej, często wpływają tym samym nie tylko na normy poprawności językowej, ale i komunikacyjnej. Zmiany w języku najwyraźniej widać w obrębie tej grupy, ponieważ są dla niej naturalne i akceptowane przez samych jej członków.

Używanie słów młodzieżowych jest podobne do gry językowej (wykorzystuje się środki pozajęzykowe, takie jak np. emotikony, przejawem zabawy jest również zapisywanie słów angielskich po polsku, a polskich po angiel-

5 Zachowania językowe urzeczywistniają się na poziomach biologiczno-fizycznym, psychicznym i społecznym (Grabias 1997, 245). 
sku) ${ }^{6}$. Kultura, w której żyje współczesna młodzież, określa ich sposób komunikowania się (leksykę, styl), który z kolei wpływa na kulturę (także: kulturę języka). Młodzieżowe słowa tworzą kod pokoleniowy pozwalający na szybką wymianę specjalnie ,zaszyfrowanych” informacji. Warto zauważyć trwałość i zmienność w słownictwie młodzieży (Pachowicz 2018, 32). Każde pokolenie może być rozpoznawane właśnie dzięki specyficznej leksyce używanej w kontaktach z rówieśnikami. Zmienność słownictwa oraz proces tworzenia nowych słów i znaczeń przez młodych ludzi odnosi się do wszystkiego, co ich otacza. Współcześnie jednak to multimedia i nowe technologie sprzyjaja powstawaniu nowych znaczeń. To z kolei można rozpatrywać w kategoriach mody językowej (Markowski 2005, 211), która daje poczucie odrębności i wzmacniania więzi grupy (Ożóg 2004, 87). Młodzież współtworzy modę językowa przez to, że ją ,upowszechnia, dodatnio wartościuje, a członkowie grupy się jej poddają" (Ożóg 2004, 90). Nowatorstwo językowe, jakim jest nadawanie nowych znaczeń i tworzenie młodzieżowych słów, nie kończy się, ale będzie podtrzymywane przez kolejne pokolenia, które wprowadzą do polszczyzny nowe słownictwo.

\section{Bibliografia}

Bałandynowicz A., 2018, Cyberprzestrzen jako facylitacja degeneratymnych zachowan mtodzieży, w: Kwadrans L., Sowa-Behtane E., Stańkowski B., red., Młodż. Przeciwko czemu sie buntuja? Crego pragna? Co buduja?, Kraków.

Bartmiński J., 2001, Styl potoczny, w: Bartmiński J., red., Wspótczesny jezylk polski, Lublin.

Chaciński B., 2003, Wypasiony stownik najmtodszej polszczyzny, Kraków.

Czeszewski M., 2001, Stownik slangu młodzieżowego, Piła.

Dzioba R., 2005, Netspeak - nowa bybryda jezylkowa, w: Dytman-Stasieńko A., Stasieńko J., red., Jezyk@multimedia, Wrocław.

Gajda J., 1987, Telewizja, mtodzię̇, kultura, Warszawa.

Grabias S., 1997, Jezyk w zachowaniach społecznych, Lublin.

Grabias S., 2001, Środowiskowe i zawodowe odmiany jezyka - socjolekty, w: Bartmiński J., red., Wspótczesny jezylk polski, Lublin.

Karwat M., Milanowski W., 1981, Młodzieżjako pržedmiot i podmiot polityki. Mtodzież-ruch mtodzię̇owy - polityka, t.1, Warszawa.

Kowalikowa J., 1996, Jezylk nauczyciela i ucznia w komunikacji sžkolnej, w: Kania S., red., Wokót spotecznego zróżnicowania jezylka, Szczecin.

Kulas H., 1986, Samoocena mtodzięzy, Warszawa.

\footnotetext{
${ }^{6}$ Warto zaznaczyć, że w momencie gdy słowo polskie z końcówką angielską -ing (spacering, plażing) będzie używane powszechnie np. w mediach, reklamach, wtedy przestaje być słowem młodzieżowym.
} 
Marcjanik M., 2008, Kody gržeczności jako forma identyfikacji z. grupa, w: „Kultura Współczesna. Teoria. Interpretacje. Praktyka", nr 2.

Markowski A., 2005, Kultura jezyka polskiego. Teoria. Zagadnienia leksykalne, Warszawa.

Messyasz K., 2013, Obrazy mtodzieży polskiej w dyskursie prasowym. Młodzież o sobie i o rz̨eczywistości spotecznej, Lódź.

Ożóg K., 2002, Kod ograniczony wśród wspótczesnej polskiej młodzৃieży, „Polonistyka”, nr 9.

Ożóg K., 2004, Polszczyzna pržełomu XX i XXI wieku. Wybrane zagadnienia, Rzeszów.

Pachowicz M., 2018, Leksyka młodzieży. Tradycja, roz̧wój, kreatywność, Kraków.

Pilczuk B., Pilczuk A., 2013, O jezyku mtodzieżowym - takize dla bibliotekarzy, „Poradnik Bibliotekarza", nr 7-8.

Pisarek W., 1991, Hasto - zróżnicowanie jezykea narodowego, w: Urbańczyk S., red., Encyklopedia jezyka polskiego, Wrocław - Warszawa - Kraków.

Seretny A., 2010, Rozwijanie kompetencji leksykalnej uczacych sie przez obcowanie z tekstem, „Acta Universitatis Lodziensis, Kształcenie Polonistyczne Cudzoziemców”, nr 17.

Tomaszewska H., 2012, Młodzię், rówieśnicy i nowe media: społecæne funk.cje technologii komunikacyjnych w życiu nastolatków, Warszawa.

Zgółkowa H., 1991, Specyfika jezylka młodrieżowego w śmiadomości uczniów, „Socjolingwistyka”, nr 11.

\section{Netografia}

https://sjp.pwn.pl/ciekawostki/haslo/Rozstrzygniecie-plebiscytu-mlodziezowe-slowo-roku2018-komentarz-Marka-Lazinskiego;6477396.html [dostęp: 20.05.2019].

https://sjp.pwn.pl/ciekawostki/haslo/Rozstrzygniecie-plebiscytu-mlodziezowe-slowo-roku2018-komentarz-Bartka-Chacinskiego;6477398.html [dostęp: 20.05.2019].

Kamila Kuros-Kowalska - dr, Instytut Językoznawstwa, Uniwersytet Śląski w Katowicach, Katowice, Polska.

Językoznawca i logopeda, adiunkt w Instytucie Językoznawstwa na Wydziale Humanistycznym Uniwersytetu Śląskiego w Katowicach. W 2016 roku obroniła z wyróżnieniem rozprawę doktorską zatytułowaną Metody stymulowania rozwoju słownictwa w języku polskim u dzieci dwujęzycznych na emigracji. Autorka i współautorka wielu publikacji, zwłaszcza z zakresu logopedii, bilingwizmu, lapsologii, lingwistyki dyskursu i kultury języka. W działalności badawczej oraz praktyce logopedycznej koncentruje się w szczególności na zagadnieniach związanych z dwujęzycznością i zaburzeniami mowy. Zainteresowania naukowe to bilingwizm, akwizycja języka, zaburzenia językowe, sprawności językowe i komunikacyjne. Najważniejsze publikacje: Poprawność językowa i jej wpływ na komunikację wśród dzieci i młodzieży ze szkół polskich za granicą (Kielce 2019, współautor: N. Moćko), Diagnoza poziomu słownika dziecka dwujęzycznego w języku prymarnym i sekundarnym. Studium przypadku (Katowice 2016), Komunikacja międzyludzka w opinii współczesnych uczniów - przyczyny powstawania barier komunikacyjnych i sposoby radzenia sobie z nimi (Kraków 2014, współautor: N. Moćko).

Kontakt: kamila.kuros@gmail.com 